10. Zuikov, A. L. Raspredelenie azimutal'nyh skorostei v laminarnom kontrvihrevom techenii [Text] / A. L. Zuikov, G. V. Orehov, V. V. Volshanik // Vestnik MGSU. - 2013. - No. 5. - P. 150-161.

11. Kalashnik, M. V. Tsiklotroficheskoe prisposoblenie v zakruchennyh gazovyh potokah i vihrevoi effekt Ranka [Text] / M. V. Kalashnik // ZhETF. - 2008. - Vol. 133, No. 4. - P. 935-947.

\section{ВЛИЯНИЕ КОНСТРУКЦИИ ЗАВИХРИТЕЛЯ ВХОДНОГО ПОТОКА} НА ГИДРОДИНАМИКУ И ЗФФЕКТИВНОСТЬ РАБОТЫ

Исследовано влияние конструкции завихрителя и места его установки в газоходе для подачи газопылевого потока на эффективность работы вихревого аппарата. Доказано, что конструкция завихрителя при соответствующих условиях позволяет закрученному потоку добиваться максимально возможной для данной конструкции угловой скорости вращения газового потока. Разработана принципиальная конструкция вихревого пылеуловителя, которая позволяет повысить эффективность очистки с помощью вихревого аппарата до 98-99\%.

Ключевые слова: конструкция завихрителя, агломерация пыли, угловая скорость вращения газового потока.

Pitak Inna, PhD, Associate Professor, Department of Chemical Technique and Industrial Ecology, National Technical University «Khar kiv Polytechnic Institute», Ukraine, e-mail: ipitak5@gmail.com, ORCID: http://orcid.org/0000-0002-5073-2942

Briankin Serhii, Head of Course of the Faculty of Military Training, National Technical University «Kharkiv Polytechnic Institute», Ukraine e-mail: serzh2082@ukr.net, ORCID: https://orcid.org/0000-00030444-9107

Pitak Oleg, PhD, Associate Professor, Department of Labour Protection and the Environmental, National Technical University «Kharkiv Polytechnic Institute», Ukraine, e-mail: opitak77@gmail.com ORCID: https://orcid.org/0000-0001-5912-4604

Shaporev Valery, Doctor of Technical Sciences, Professor, Department of Chemical Technique and Industrial Ecology, National Technical University «Kharkiv Polytechnic Institute», Ukraine, ORCID: http://orcid.org/0000-0003-1652-4688

Petrukhin Serhii, PhD, Associate Professor, Department of Radia tion, Chemical, Biological Protection, National Technical University «Kharkiv Polytechnic Institute»,Ukraine, e-mail: s_petruhin@ukr.net, ORCID: http://orcid.org/0000-0003-4228-4622
Shkop A., Briankin 0., Shestopalov 0., Ponomareva $\mathbf{N}$.

\title{
INVESTIGATION OF THE TREATMENT EFFICIENCY OF FINE-DISPERSED SLIME OF A WATER ROTATION CYCLE OF A METALLURGICAL ENTERPRISE
}

Досліджені особливості очищення шламів водооборотного циклу металургійного виробництва. Виявлено, що надходження завислих часток в шламові води відбувається періодично і нерівномірно. Встановлено, що шлами газоочищення металургійного підприємства містять до 93 \% дрібнодисперсної фракції твердої фази класу менше 20 мкм. Рекомендовано застосування лабораторних тестів якості шламу і ефективності флокулящії. В ході промислових випробувань встановлена можливість очищення шламу з ефективністю до 99 \% флокуляційно-відиентровим способом із застосуванням методики лабораторних тестів.

Ключові слова: газоочищення металургійного підприємства, дрібнодисперсні шлами, илами газоочищення, модуль очищення.

\section{Introduction}

According to various sources, more than 70 million tons of slimes have been accumulated at metallurgical enterprises in Ukraine, of which about a third are suitable for reuse [1]. At the metallurgical industry, the greatest amount of water is used as a cooler for steelmaking furnaces and converters, as well as for wet gas treatment systems. The wastewater that is formed is contaminated with solid suspended particles and has dissolved chemicals, for example, hardness salts. For example, the volume of sewage discharged by enterprises of ferrous and nonferrous metallurgy in Ukraine reaches 500 million $\mathrm{m}^{3} /$ year.

In industrial processes and technologies, the greatest amount of water is used as a coolant, solvent, transport agent. In metallurgy, wastewater is formed mainly after cooling of steel-smelting converters and after wet treatment of gases.

The amount of sewage and slime of wet gas treatment is up to $10 \mathrm{~m}^{3}$ per $1000 \mathrm{~m}^{3}$ of gas, which corresponds to approximately $4-5 \mathrm{~m}^{3}$ per $1 \mathrm{~m}$ of melted steel.

The use of sewage in the water cycle system of enterprises because of the high content of chemical compounds in concentrations unacceptable by existing norms for circulating water requires their treatment. In order to reuse slime in gas treatment, they must be clarified to a residual suspended matter content of $150-200 \mathrm{mg} / \mathrm{dm}^{3}$.

The discharge of contaminated sewage into the external slime collectors of metallurgical enterprises leads to secondary contamination of soils and groundwater with heavy 
metals, alienation and salinization of lands, technogenic transformation of the natural landscape [2]. Millions of tons of iron-containing slimes have already been accumulated around metallurgical enterprises and their processing is complicated by difficulties of condensation to the required humidity for subsequent disposal [3].

Proceeding from the foregoing, the study of the regularities of the processes of cleaning and dewatering of slimes of metallurgical enterprises, as well as the search for ways to intensify processes and utilize slime components, is an actual scientific and technical task.

\section{The object of research and its technological audit}

The object of research is the process of wastewater treatment from suspended solids, formed as a result of wet gas scrubbing of off-gases of the oxygen-converter shop of one of the metallurgical enterprises. The current scheme of recycling water supply of gas treatment is shown in Fig. 1.

From the gas treatment modules (2) of converters (1) the slime pulp by the self-flowing slime pipeline enters the receiving bunkers-hydroclassifiers (3) with suspended substances up to $12 \mathrm{~g} / \mathrm{l}$. In the bunkers-hydroclassifiers there is a separation of slime pulp by fractions. The coarse fraction (particles larger than $2 \mathrm{~mm}$ ) is withdrawn along the vertical slime pipeline through the adjusting nozzle into the receiving tray. The finer fraction (particles smaller than $2 \mathrm{~mm}$ ) is taken along the vertical slime pipelines into the receiving tray. From the receiving tray from the vertical slime pipelines, a large water-emulsion fraction is distributed through pendulum feeders through large-scale treatment facilities, namely to the «left» or «right» section of the horizontal sedimentation tank (9). The capacity of the section of the horizontal sedimentation tank is $250 \mathrm{~m}^{3}$, the time of filling with slime is $4-6$ days. The slime with a grab crane is discharged from the sedimentation chamber of the sedimentation tank into the railway cars and sent for re-use to the sinter plant.

The finely dispersed fraction that does not settle at the sites of hydroclassification is distributed along the hydrocyclone flocculators (4), where it thickens on the bottom, and clarified hot water is piped through three-section cooling towers and a spray-type fan cooling tower (12). Cooling towers cool the recycled water with the concentration of suspended particles up to $200 \mathrm{mg} / \mathrm{l}$.

The sedimentary suspension of the fine fraction under the action of gravity and centrifugal forces in the hydrocyclone-flocculator is condensed by a farm working automatically with scrapers and a conical bottom of the flocculator. Adjusting the flow rate of the slime suspension along the flocculants is carried out using nutrient latches.

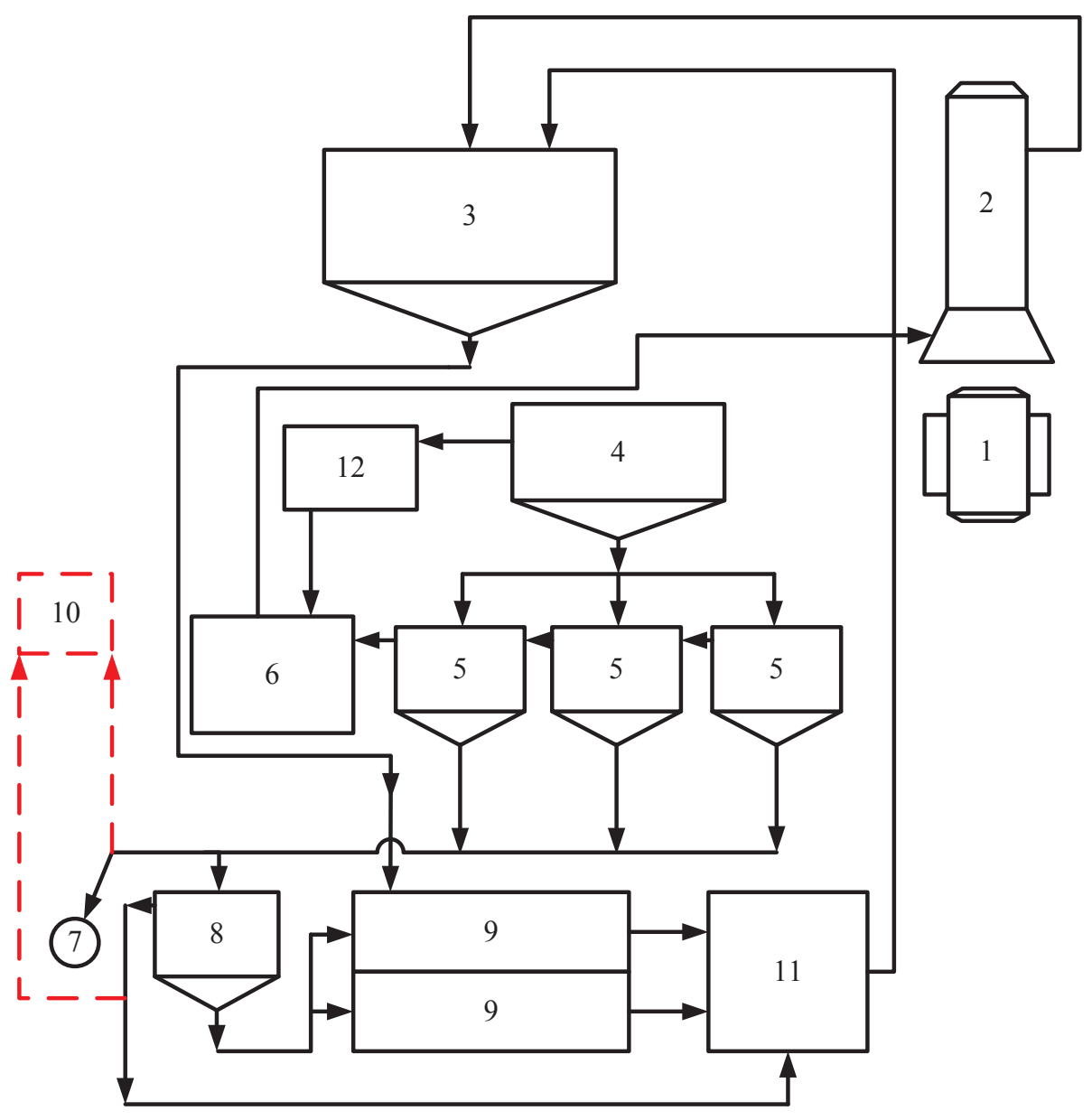

Fig. 1. Schematic diagram of the current system of water recycling of gas treatment of oxygen-converter shop:

1 - converter; 2 - wet gas treatment; 3 - bunkers-hydroclassifiers; 4 - flocculator; 5 - radial thickeners; 6 - clarified water tank; 7 - discharge to the slime collector; 8 - bunker-collectors of fine fraction; 9 - horizontal sedimentation tanks; 10 - location of the treatment module during the test; 11 - chamber of the pre-clarified water; 12 - cooling towers 
The thickened slime suspension is diverted from the cone bottom of the hydrocyclone-flocculator through the slime pipeline to the receiving chamber of the thickeners. From it the pulp along the slime pipeline is evenly distributed by means of nutritional valves on the radial thickeners (5). Water that is clarified in radial thickeners is collected in a clarified water tank (6), from where it is fed to a second wet gas treatment after the converters.

The thickened slime pulp of the thickeners is pumped in turn by one of the working slime pumps and fed to the hydroclassifier of the bunker-collectors (8).

Overflows of all bunkers and sections of the horizontal sedimentation tank along a gravity chute are fed into the chamber of the pre-clarified water (11) with a suspended matter content of 20-35 g/l from which pumping units are pumped to the bunker of the hydroclassification unit (3) to re-sedimentation the suspended particles.

One of the most problematic areas in this process is the low treatment efficiency of the highly dispersed slime, resulting in the removal of the fine fraction of solid particles together with the clarified water of the radial thickeners. This leads to the need for regular replenishment and dilution of clarified water, repeated treatment of the pre-clarified water and discharge of part of the flow to the slime collectors. This is due to the fact that the finely dispersed phase does not completely settle in the radial thickeners even after flocculation in the hydrocyclone-flocculants, is removed from them and pollutes the recycled water. The reason for this is the fact that with continuous operation of the water cycle of wet gas treatment, the load on the main water treatment devices (primarily flocculants) can exceed the design values. This is a consequence of two reasons:

- increase in the load from gas treatment and over-

flows into the main line of the pre-clarified water of the condensed slime of the radial thickener during overloading into storage bunkers;

- decrease in the sedimentation rate of fine particles due to overdose of chemical reagents (flocculants), which leads to an increase in the viscosity and stabilization of the slime suspension.

The foregoing circumstances lead to a periodic deterioration in the quality of water treatment by flocculators and radial thickeners.

When the limiting contamination of the treated water with flocculants is reached, in order to maintain the amount of suspended matter in the circulating water within the established norm of $200 \mathrm{mg} / \mathrm{l}$, a «system purge» is performed - the discharge of the condensed product of radial thickeners into the external slime collector (7) and refill the system with clean water.

The absence of a single scientifically grounded approach to describing the specifics of the processes occurring in flocculation of fine slimes and silt leads to the need for additional laboratory studies and industrial tests of equipment for treatment of real sewage in each specific case. Therefore, in order to identify the possibility of trapping small particles and returning treated water to the water circulation, industrial tests were carried out using a sewage treatment module БФЯИ 3400.00.00.000 (hereinafter Module) produced by the Scientific and Production Center Ecomash (Kharkiv, Ukraine).

The treatment module for suspended solids is an automated chain of equipment that includes a flocculant prepa- ration station, a thin-layer sedimentation tank and sedimentation horizontal screw centrifuge (GSS). Treatment from suspended solids is carried out by solids sedimentation in the field of gravitational and centrifugal forces. Intensification of sedimentation processes occurs due to the use of flocculants. The thickened product of the thinlayer sedimentation tank is dewatered in a sedimentation centrifuge. The slime water treatment module works in a continuous mode with correction of the flocculant consumption depending on the concentration of the solids in the slime. The dosing of the flocculant is carried out by the automated control system.

The adjustment of the Module's technology is preceded by laboratory studies of slime waters, according to the results of which, the mode of operation of the modules is adjusted. The circuit diagram of the Module circuit is described in more detail in [4].

\section{The aim and objectives of research}

The aim of research is improvement of the treatment system and development of technical solutions for the reconstruction of a complex of equipment for capturing finely divided slime of gas treatment by various methods of dehydration.

To achieve this aim it is necessary:

1. To analyze the features of the treatment system of slime waters of the water cycle of wet gas treatment.

2. To conduct laboratory studies of the composition and properties of real slimes of the water cycle of wet gas treatment.

3. To conduct industrial tests for the treatment of metallurgical slime and determine the effectiveness of the method of laboratory tests.

\section{Research of existing solutions of the problem}

The main method of using slime gas treatment of converters is the addition of them to the sintering charge. For the slime disposal at the sinter plant, the converter slime must be previously dehydrated. The most common scheme for slime dewatering at metallurgical plants is a scheme that provides thickening of slime pulp in radial thickeners and sedimentation tanks of various designs [5], filtration on filter presses or drying in drying drums.

Sewage from gas treatment of oxygen-converter plants, open-hearth furnaces and electric steel-smelting furnaces belong to insufficiently studied varieties of sewage. The main distinguishing feature of this wastewater is an extremely uneven composition of contaminants during one technological cycle (smelting), depending on many factors, for example, the composition of the charge.

As a rule, sewage from the gas treatment system of the metallurgical plant contains a large number of fine particles and is complex polydisperse suspensions [1]. For the treatment of highly disperse slimes containing a complex chemical solids composition, the chemical enhancement of sedimentation processes is applied by introducing flocculants and coagulants [6, 7]. General recommendations for the use of reagents in the treatment of slime waters are reduced to the selection of the type and dose of reagents to purify a particular type of slime of a certain concentration and physico-chemical properties. 
Non-ionic flocculants [8, 9], ionogenic (cationogenic and anionic) flocculants [10], their combination among themselves [11], coagulants in combination with flocculants are used among the methods of intensifying the treatment of slimes of various industries with a polydisperse composition [12, 13].

Despite the abundance of publications on flocculationcoagulation of slimes of various origins in the practice of water treatment, it is necessary to select the necessary reagent and equipment, providing in aggregate the required treatment efficiency, depending on the features of the process in each specific case. This is due to the multifactor process of aggregation of particles, which depends on the dispersion and solids concentration [14, 15], $\mathrm{pH}$, the content of dissolved salts [16], etc.

For these purposes, it is necessary to carry out both laboratory studies and industrial tests on actual slimes of existing production.

\section{Methods of research}

The study is conducted in two stages: in laboratory and industrial conditions.

Laboratory studies of samples of slime waters for wet gas treatment of the oxygen-converter shop, taken from different places of the water rotation cycle, are carried out for the following:

1) determination of the granulometric composition and distribution of slime mass by classes using the BA-B01 vibration analyzer (Ukraine);

2 ) in the samples of slime waters, the content of suspended solids in $1 \mathrm{dm}^{3}$ is determined by the standard method;

3) density of the solid slime product is calculated, both the mean value and the slime density in each separate class.

To determine the slime density of different fractions, slime samples collected in the radial thickeners are screened through sieves with 20,40,60, 100 micron gaps. The resulting solids are mixed with the clarified water, the density of which is $1002.1 \mathrm{~kg} / \mathrm{m}^{3}$. The sedimentation kinetics is measured and the density of each fraction is calculated.

Based on the results of determination of slime density, the slime pulp density is calculated as a function of the solids content. The materials are designed as a plot of the weight of 11 of pulp from the dry mass of the solids. The results of the calculation are compared with the actual slime samples.

To assess the effectiveness of the chemical reagents currently used for the flocculation of wet scrubbing slime, the dosage is compared in the test samples of the anionic flocculant ТФК-19 and the reagents of the anionic flocculant PuroFloc 1011 and the PuroTech RO510 coagulant used in the enterprise. The reagents are added to a $500 \mathrm{ml}$ slime sample with a solids concentration of $1331.5 \mathrm{mg} / \mathrm{l}$ in a variety of combinations and amounts. After mixing the samples, the rate of slime floccule sedimentation is determined before and after the mechanical influences according to the method of laboratory tests described in [14, 15].

In the course of industrial tests, slime waters with a variable content of suspended solids from $20 \mathrm{~g} / 1$ to $280 \mathrm{~g} / \mathrm{l}$ are fed to the treatment Module. In the course of the tests, the performance of the slime water treatment and slime dehydration Module is recorded. For this, samples of the original slime, treated after the water Module (centrifuge centrate) and sediment, are taken.

\section{Research results}

6.1. Research results of the current water rotation circuit. During the analysis of the operating water rotation circuit, measurements of the solids content in the thickened product of radial thickeners are carried out. This product through the collector (with a total flow rate of $\leq 85 \mathrm{~m}^{3} \mathrm{~h}$ as the radial thickener is emptied) is fed to bunker-collectors. Measurements of the content of the solid in the pre-clarified water entering the bunkerhydroclassifiers are also carried out. The results of these measurements are shown in Fig. 2.

The average value of the solids content in the radial thickener slime is $200 \mathrm{~g} / \mathrm{l}$, which corresponds to a load of $17 \mathrm{t} / \mathrm{h}$. Attention is drawn to the fact that for 8.5 hours out of 16 hours the average solids content in the collector of the radial thickener is below $200 \mathrm{~g} / \mathrm{l}$ and is $88 \mathrm{~g} / \mathrm{l}$ (the average load in the collector is $7.5 \mathrm{t} / \mathrm{h}$, with 4 hours out of 16 hours, the available load is actually below $4 \mathrm{t} / \mathrm{h}$ ).

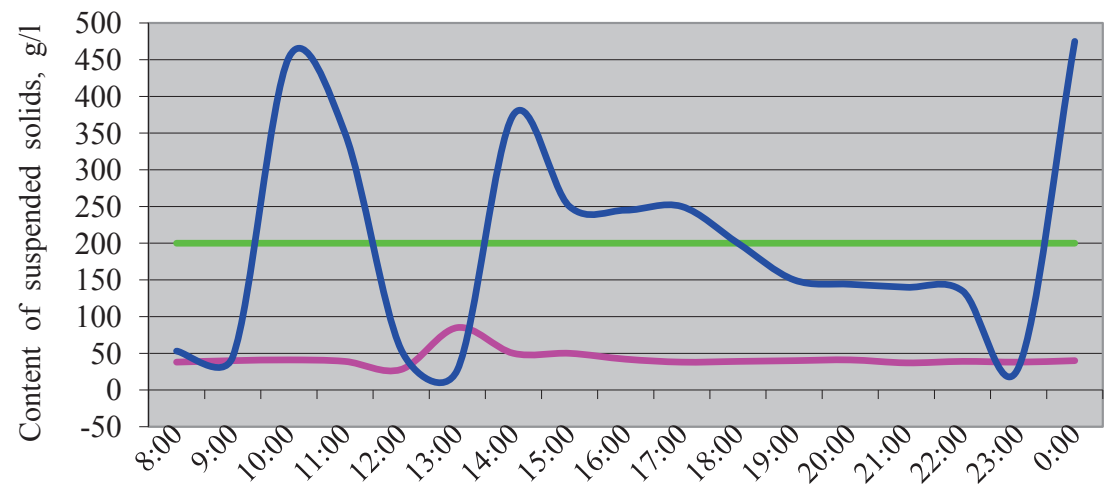

Time, hour

-Average content of suspended solids, g/l

Content of suspended solids in pre-clarified water, g/l

Content of suspended solids in thickened slime, $\mathrm{g} / \mathrm{l}$

Fig. 2. Graph of the change in the solids content in the slime of the radial thickener and the pre-clarified water 
The results of laboratory studies of the granulometric composition and solids concentration in slime samples taken at different points of the water circuit are presented in Table 1.

The average solids value in the pre-clarified water is $35 \mathrm{~g} / \mathrm{l}$, which corresponds to a load of $24 \mathrm{t} / \mathrm{h}$, and when the solids content is increased to $85 \mathrm{~g} / \mathrm{l}$, the load is increased to $59.5 \mathrm{t} / \mathrm{h}$.

The average density of the solid product of slimes, the density of slimes according to the classes of the granulometric composition, hydraulic size according to the classes of granulometric composition is shown in Table 2. The average density of the solids in the slime is $3928.9 \mathrm{~kg} / \mathrm{m}^{3}$.

Fig. 3 is a graph of the weight of 11 of slime water pulp on the slime content in it. The dots denote the results of weighing and determination of the solids content in a liter of slime according to the laboratory. The line represents the results of calculating the solids concentration in the slime volume, depending on its weight at an average solids density of $3900 \mathrm{~kg} / \mathrm{m}^{3}$. This dependence makes it possible to determine the approximate concentration of solids in a liter of slime by weighing for the operational control of the concentration and adjustment of the slime treatment technology, for example, the dose of chemical reagents.

Comparison of dosage in test samples of anionic flocculant TФA-19 and reagents used at the enterprise: anionic flocculant PuroFloc 1011 and coagulant PuroTech RO510 (Fig. 4).

As a result of the tests, it is found that when using an anionic flocculant (test No. 1), sufficiently high deposition rates are obtained with less reagent costs (almost 10 times less compared to test No. 2). This allows to recommend the use of anionic flocculant for the treatment of slimes in the water rotation cycle.

Table 1

Granulometric composition and concentration of solids in slime samples

\begin{tabular}{|c|c|c|c|c|c|}
\hline \multirow{2}{*}{ Place of sampling } & \multicolumn{4}{|c|}{ Class yield, $\mu \mathrm{m}$} & \multirow{2}{*}{$\begin{array}{l}\text { Solids concentra- } \\
\text { tion, } \mathrm{g} / \mathrm{l}\end{array}$} \\
\hline & $<20$ & $20 \ldots 40$ & $60 \ldots 40$ & $>60$ & \\
\hline Slime after wet gas treatment & 92.98 & 3.51 & 3.51 & 0 & 2.28 \\
\hline Thickened product of the bunker-hydroclassifier & 86.45 & 10.24 & 3.31 & 0 & 26.56 \\
\hline Thickened product of flocculants of hydrocyclone type & 91.02 & 7.18 & 1.8 & 0 & 6.68 \\
\hline Thickened product of radial thickener & 79.24 & 11.12 & 6.955 & 2.685 & 338.2 \\
\hline Sample of pre-clarified water & 50.76 & 44.61 & 4.63 & 0 & 84.56 \\
\hline
\end{tabular}

Table 2

Dependence of the density and kinetics of solids sedimentation on the particle size

\begin{tabular}{|c|c|c|c|c|c|}
\hline Particle size, $\mu \mathrm{m}$ & $\begin{array}{c}\text { Weight of 1 } \mathrm{l} \\
\text { of suspension, } \mathrm{g}\end{array}$ & Solids content, $\mathrm{g} / \mathrm{l}$ & Solids density, $\mathrm{kg} / \mathrm{m}^{3}$ & Yield, \% & $\begin{array}{c}\text { Sedimentation rate of the } \\
\text { particles, mm/s }\end{array}$ \\
\hline $200 \ldots 100$ & 1006.1 & 10.15 & 1653.9 & 3.684 & $6.75 \ldots 3.5$ \\
\hline $100 \ldots 63$ & 1006 & 8.85 & 1791.6 & 3.212 & 1.7 \\
\hline $63 \ldots 40$ & 1004.5 & 7.95 & 1435.4 & 2.885 & $0.9 \ldots 0.56$ \\
\hline $40 \ldots 20$ & 1007.75 & 10.4 & 2194.1 & 3.774 & $0.64 \ldots 0.28$ \\
\hline $20 \ldots 3$ & 1032.7 & 40 & 4264.3 & 86.445 & $0.7 \ldots 0.016$ \\
\hline
\end{tabular}

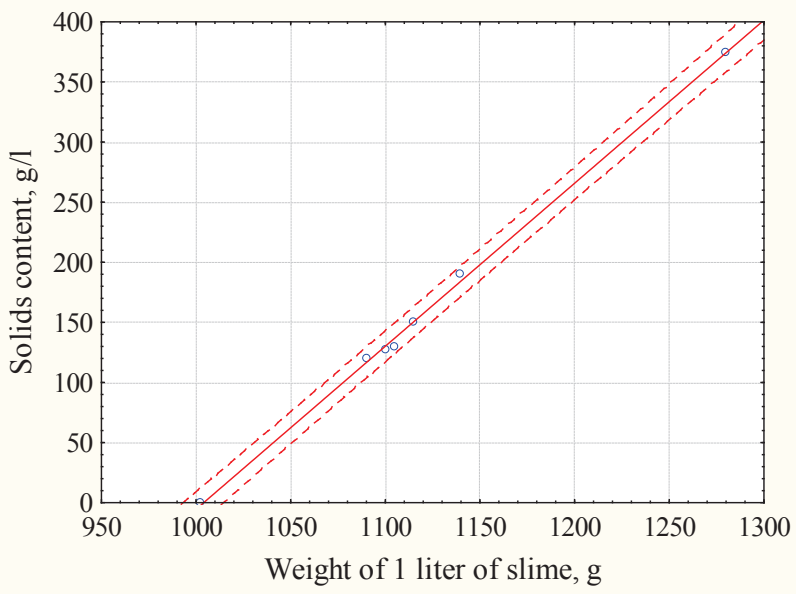

Fig. 3. Dependence of the weight of 1 liter of pulp of slime waters on the solids content in it 


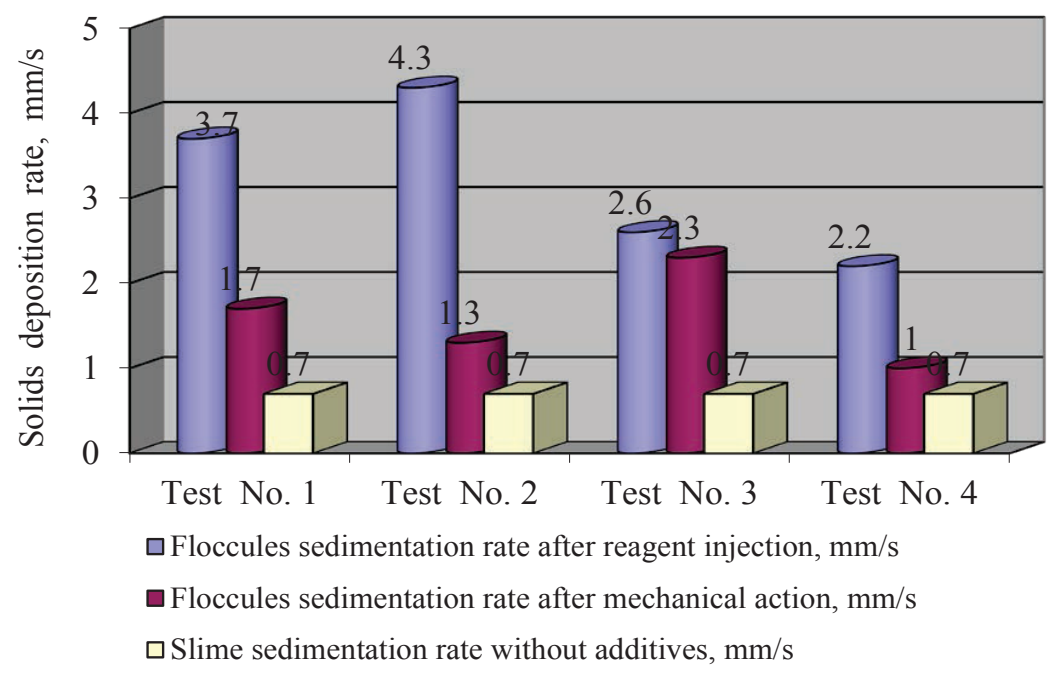

Fig. 4. Solids sedimentation rate during tests:

test No. 1 - addition of an anionic flocculant ТФА-19 in an amount of $37.57 \mathrm{~g} / \mathrm{t}$; test No. 2 - addition of a mixture of coagulant plus flocculant (PuroTech R0510 and PuroFloc 1011) in an amount of 281+75.1=356.1 g/t; test No. 3 - addition of flocculant PuroFloc 1011 in an amount of $75.1 \mathrm{~g} / \mathrm{t}$; test No. 4 - addition of a mixture of coagulant plus flocculant (PuroTech $\mathrm{B0510}$ and ТФА-19) in the amount of $37.57+281=318.57 \mathrm{~g} / \mathrm{t}$

6.2. Results of industrial tests for water rotation treatment. In the course of industrial tests, it is revealed that in the pre-clarified water supplied to the Module, there is an excessive amount of chemical reagents (Purotech RO 510 and Puroflock 1011) added to the slime water in the sections of the classifier and flocculant bunkers. This leads to unstable aggregation of particles and variable rates of deposition in the field of gravitational forces. Sedimentation of incoming slime in laboratory cylinders shows the presence of small floccules with the sedimentation rate from 0.7 to $6 \mathrm{~mm} / \mathrm{s}$.

With a minimum residual content of chemical agents Purotech RO 510 and Puroflock 1011 in the Module supply (when the slime sedimentation rate is less than $1 \mathrm{~mm} / \mathrm{s}$ ), a stable treatment efficiency of the clear water using the ТФA-19 anionic flocculant is achieved. The flow of the flocculant into the Module is made based on laboratory tests in chemical containers and tests from the Modules in operation. At the same time, the results of laboratory tests practically coincide, which makes it possible to predict the results of slime water treatment in the Module with high reliability according to preliminary tests of samples.

During the testing of the Module with treatment with different centrifuges such as ОГШ, it is found that the dosage of flocculant TФA-19 in small amounts (about 60 to $80 \mathrm{~g} / \mathrm{t}$ ) makes it possible to achieve a treatment degree of slime waters of wet gas treatment from suspended solids of $98-99 \%$ (less than $200 \mathrm{mg} / \mathrm{l}$ ), while the moisture content of the dehydrated sediment is $27-30 \%$.

6.3. Analysis of the results of work. In the process of studying the operation of the sewage water treatment system for the water rotation cycle of the wet gas scrubbing of the oxygen-converter shop, the following features are established. When the wet gas treatment system is in operation, the input of suspended solids into slime waters occurs periodically and unevenly (Fig. 2). The intake of suspended solids depends on the cyclic operation of the converter, the number of operating converters (one or two), the type of charge and other factors.
The amount of supplied chemical reactants is not regulated, depending on the amount of suspended matter in the slime waters. During the operation of the wet gas treatment system, an overdose of chemical reagents is observed. This is due to the increase in the dose of reagents depending on the purity of clarified water. As a result of the influx of excess flocculants, the subsequent flocculation of the slime and the destruction of the floccules, a residual flocculant is accumulated in the circulation water, representing scraps of the polymer chain. The presence of residual flocculant in the subsequent cycle leads to a low efficiency of the new portion of the reagents, since the residues of the non-operating flocculant prevent the adsorption of a new portion of the same-named flocculant (cationic). Thus, a decrease in the sedimentation degree in radial thickeners and horizontal sedimentation tanks is observed, an increase in the removal of the finely dispersed solids and contamination of the recycled water. This, in turn, leads to an increase in the consumption of reagents without the selection of new (for example, oppositely charged) with a decrease in the treatment quality. This trend continues until a part of the return water is dumped and the system is fed with clean water.

The sieve analysis (Table 2) of the main slime flow shows that $80-93 \%$ of finely dispersed particles with a particle size of less than $20 \mu \mathrm{m}$ and a density of $\sim 4.3 \mathrm{~g} / \mathrm{cm}^{3}$ are contained in slime waters after wet gas scrubbing. The average density is $3.9 \mathrm{~g} / \mathrm{cm}^{3}$. The different density, depending on the size of the solids, may indicate a different chemical composition of particles of different sizes. Despite the high density, the kinetics of deposition of small particles in the field of gravity without the addition of reagents is very small.

When comparing the effect of different flocculants, it is found that the use of flocculant TФA-19 in the amount of $38 \mathrm{~g} / \mathrm{t}$ is rational (Fig. 4, test 1). The effectiveness of this type of flocculent will not be lower than the mixture of coagulant plus flocculant used in the enterprise (Fig. 4, test 2). At the same time, the dosage of the flocculant 
TФA-19 will be significantly lower (almost 10 times). Thus, the use of existing chemical treatment of wet gas scrubbing slime is ineffective. The use of an anionic flocculant, which is the opposite of the charge used in production, neutralizes the effect of the residual cationic flocculant accumulating in the water rotation cycle on the surface of the finely dispersed phase.

In addition, it is necessary to take into account fluctuations in the concentration of the solids in the slime, which can vary within a wide range within a day (Fig. 2). For the operational control of the solids concentration in the slime, the dependence shown in Fig. 3. Such dependence can be obtained by calculation or statistical processing of laboratory data. As a result of the data analysis (dots in Fig. 3), the equation of the dependence of the solids concentration of $C_{s}$ on the weight of a liter of slime $\mathrm{m}$ with a coefficient of determination $r^{2}=0.9985$ :

$$
C_{S}=-1363.4612+1.3607 \cdot m \text {. }
$$

Tests on the treatment Module confirm the need to adjust the flocculant consumption during operation and the possibility of efficient $(98 \ldots 99 \%)$ treatment of the slime with a minimum consumption of the flocculant. The dosage of the flocculant is rapidly changed based on the determination of the solids concentration in the slime according to formula (1) or Fig. 3, as well as determining the sedimentation rate of floccules and comparing it with test 1 (Fig. 4). Thus, the adjustment of the amount of flocculant fed to clean the slime should be based on laboratory slime samples (determination of the solids concentration) and flocculation tests.

\section{SWOT analysis of research results}

Strengths. As a result of the conducted tests, it is found that the possible way of reducing the concentration of the solids in the water cycle of metallurgical production can be the use of an additional treatment module that includes the stages of flocculation, removal and centrifugation of the slime condensed in the sedimentation tank. This makes it possible to reduce water losses as a result of preventing the discharge of part of the slime into the external slime collector and to reduce the volume of make-up water.

Weaknesses. In order to maintain an effective slime treatment regime, physico-chemical studies of their properties (change in the solids concentration), the efficiency of solids flocculation (the rate of flocculation, dose adjustment and reagent type) and the quality of water treatment should be constantly carried out.

Opportunities. The next stage of research will be the study of the factors that influence flocculation and sedimentation of highly disperse slime. This will make it possible to regulate the degree of slime treatment by intensifying the formation of aggregates without increasing the dose of reagents by improving the qualitative efficiency of the process.

Threats. The change in the water circulation scheme and the use of additional equipment and reagents provides additional material costs. In addition, effective water treatment is a multifactorial process, as changing the composition and properties of the slime requires the online management of the treatment technology as a whole and the processes in individual devices, otherwise the quality of the treated water will decrease. This requires the appropriate specialists and additional theoretical and industrial experiments.

\section{Conclusions}

1. As a result of the analysis of the operation peculiarities of the slime water treatment system, it is revealed that the system of the water rotation cycle of the wet gas scrubbing of the oxygen-converter shop has a number of drawbacks that can lead to deterioration in the treatment of the circulating water. Among them, one can single out the fluctuation of the solids concentration in the condensed slime to $500 \mathrm{~g} / \mathrm{l}$ and the pre-clarified water to $85 \mathrm{~g} / \mathrm{l}$, as well as the overexpenditure of chemical reagents.

2. The results of laboratory tests show a high proportion of the finely divided fraction of the solids in the slime to $93 \%$ with a size of less than $20 \mu \mathrm{m}$. Effective treatment of such slime with variable concentration is possible only on the basis of operational laboratory tests for flocculation before reagent inputs. For the slime of this production, the anionic flocculant ТФA-19, which reduces the negative effects of accumulation of cationic flocculant residues in the system, is highly effective.

3. As a result of industrial tests, it is established that the treatment of the pre-clarified water from suspended solids to the required norms of the water rotation cycle of $200 \mathrm{mg} / \mathrm{l}$ is ensured by the treatment unit with an anionic flocculant dosing in the amount of $60-80 \mathrm{~g} / \mathrm{t}$. In this case, the technology for treating slime waters with a flocculant should be adjusted by laboratory tests, depending on the concentration and properties of the solids.

\section{References}

1. Melnikov, I. T. Investigation of sludge thickening for mining and metallurgical production [Text] / I. T. Melnikov, I. M. Kutlubaev, I. A. Putalev, N. S. Shevtcov, K. P. Vasiluev // Scientific World. - 2013. - Vol. 14, No. 3. - P. 18-25.

2. Radovic, N. Cleaner metallurgical industry in Serbia: A road to the sustainable development [Text] / N. Radovic, Z. Kamberovic, D. Panias // Chemical Industry and Chemical Engineering Quarterly. - 2009. - Vol. 15, No. 1. - P. 1-4. doi:10.2298/ ciceq0901001r

3. Kovalenko, A. About gas purification sludges of domain and steel-smelting manufactures [Text] / A. Kovalenko // EasternEuropean Journal of Enterprise Technologies. - 2012. - Vol. 2, No. 12 (56). - P. 4-8. - Available at: \www/URL: http:// journals.uran.ua/eejet/article/view/3919/3587

4. Shkop, A. Research of ways to reduce mechanical influence on floccules in a centrifuge [Text] / A. Shkop, M. Tseitlin, O. Shestopalov, V. Raiko // Technology Audit and Production Reserves. - 2017. - Vol. 1, No. 3 (33). - P. 39-45. doi:10.15587/2312-8372.2017.93690

5. Atamaniuk, A. A. K voprosu sgushcheniia suspenzii zhelezosoderzhashchih vzvesei stochnyh vod metallurgicheskogo kombinata «Zaporozhstal» [Text] / A. A. Atamaniuk, A. M. Kasimov // Metallurgicheskaia i gornorudnaia promyshlennost. - 2012. No. 5 (227). - P. 95-97.

6. Sulimova, M. A. Metallurgical production waste treatment efficiency increase [Text] / M. A. Sulimova, T. E. Litvinova // 16th International Multidisciplinary Scientific GeoConference SGEM 2016, Conference Proceedings. - 2016. - Vol. 2. P. 569-576.

7. Sun, Y. Y. Application of Flocculant and Coagulant to Coal Slime Water [Text] / Y. Y. Sun, C. Y. Xu, R. C. Nie, J. H. Zheng // Advanced Materials Research. - 2013. - Vol. 781-784. P. 2170-2173. doi:10.4028/www.scientific.net/amr.781-784.2170

8. Tripathy, T. Flocculation: A New Way to Treat the Waste Water [Text] / T. Tripathy, B. R. De // Journal of Physical Sciences. - 2006. - Vol. 10. - P. 93-127. 
9. Bolto, B. Organic polyelectrolytes in water treatment [Text] / B. Bolto, J. Gregory // Water Research. - 2007. - Vol. 41, No. 11. - P. 2301-2324. doi:10.1016/j.watres.2007.03.012

10. Heller, H. Anionic Polyacrylamide Polymers Effect on Rheological Behavior of Sodium-Montmorillonite Suspensions [Text] / H. Heller, R. Keren // Soil Science Society of America Journal. 2002. - Vol. 66, No. 1. - P. 19. doi:10.2136/sssaj2002.0019

11. Wang, W.-D. Experimental study on slime water flocculation sediment based on the montmorillonite hydration expansion inhibition [Text] / W.-D. Wang, H.-F. Wang, J.-T. Sun, Y. Sun // Journal of Coal Science and Engineering (China). - 2013. Vol. 19, No. 3. - P. 530-534. doi:10.1007/s12404-013-0414-y

12. Lopez-Maldonado, E. A. Improving the Efficiency of a Coagulation-Flocculation Wastewater Treatment of the Semiconductor Industry through Zeta Potential Measurements [Text] / E. A. Lopez-Maldonado, M. T. Oropeza-Guzman, A. OchoaTeran // Journal of Chemistry. - 2014. - Vol. 2014. - P. 1-10. doi:10.1155/2014/969720

13. Petzold, G. Higher efficiency in the flocculation of clay suspensions by using combinations of oppositely charged polyelectrolytes [Text] / G. Petzold, M. Mende, K. Lunkwitz, S. Schwarz, H.-M. Buchhammer // Colloids and Surfaces A Physicochemical and Engineering Aspects. - 2003. - Vol. 218, No. 1-3. - P. 47-57. doi:10.1016/s0927-7757(02)00584-8

14. Shkop, A. Exploring the ways to intensify the dewatering process of polydisperse suspensions [Text] / A. Shkop, M. Tseitlin O. Shestopalov // Eastern-European Journal of Enterprise Technologies. - 2016. - Vol. 6, No. 10 (84). - P. 35-40 doi:10.15587/1729-4061.2016.86085

15. Shkop, A. Study of the strength of flocculated structures of polydispersed coal suspensions [Text] / A. Shkop, M. Tseitlin, O. Shestopalov, V. Raiko // Eastern-European Journal of Enterprise Technologies. - 2017. - Vol. 1, No. 10 (85). P. 20-26. doi:10.15587/1729-4061.2017.91031

16. Konduri, M. K. R. Influence of $\mathrm{pH}$ and ionic strength on flocculation of clay suspensions with cationic xylan copolymer [Text] / M. K. R. Konduri, P. Fatehi // Colloids and Surfaces A: Physicochemical and Engineering Aspects. - 2017. - Vol. 530. P. 20-32. doi:10.1016/j.colsurfa.2017.07.045

\section{ИССЛЕДОВАНИЕ ЭФФЕКТИВНОСТИ ОЧИСТКИ МЕЛКОДИСПЕРСНОГО ШЛАМА ВОДООБОРОТНОГО ЦИКЛА МЕТАЛЛУРГИЧЕСКОГО ПРЕДПРИЯТИЯ}

Исследованы особенности очистки шламов водооборотного цикла металлургического производства. Выявлено, что поступление взвешенных веществ в шламовые воды происходит периодически и неравномерно. Установлено, что шламы газоочисток металлургического предприятия содержат до $93 \%$ мелкодисперсной фракции твердой фазы класса менее 20 мкм. Рекомендовано применение лабораторных тестов качества шлама и эффективности флокуляции. В ходе промышленных испытаний установлена возможность очистки шлама с эффективностью до 99 \% флокуляционно-центробежным способом с применением методики лабораторных тестов.

Ключевые слова: газоочистка металлургического предприятия, мелкодисперсные шламы, шламы газоочистки, модуль очистки.

Shkop Andrii, PhD, Director, LTD «Scientific and Technical Center «Ecomash», Kharkiv, Ukraine, e-mail: shkop ecomass@ukr.net, ORCID: https://orcid.org/0000-0002-1974-0290

Briankin Oleksandr, Postgraduate Student, Department of Chemical Technique and Industrial Ecology, National Technical University «Kharkiv Polytechnic Institute», Ukraine, e-mail: bryankin@i.ua, ORCID: https://orcid.org/0000-0002-7897-4417

Shestopalov Oleksii, PhD, Associate Professor, Department of Chemical Technique and Industrial Ecology, National Technical University «Kharkiv Polytechnic Institute», Ukraine, e-mail: shestopalov.it@khpi.edu.ua ORCID: https://orcid.org/0000-0001-6268-8638

Ponomareva Natalya, PhD, Associate Professor, Department of Integrated Technologies, Processes and Devices, National Technical University «Kharkiv Polytechnic Institute», Ukraine, ORCID: https://orcid.org/0000-0001-8931-5882

\section{Shkop A., Briankin 0. Shestopalov 0., Ponomareva $\mathbf{N}$}

\section{INVESTIGATION OF FLOCCULATION EFFICIENCY IN TREATMENT OF WET GAS TREATMENT SLIME OF FERROALIOYS PRODUCTION}

Досліджені склад і особливості флокулящї шламів водооборотного ииклу виробництва феросплавів. Виявлено, що хімічний склад $і$ конщентрачія твердої фази шламів змінюється в часі. Встановлено, що особливості змішення шламів з флокулянтом грають важливу роль у флокулоутворенні. Для очищення шламів рекомендовано вводити флокулянт двома пориіями 35-40\% i 60-65\% відповідно з часом змішення до 30 секунд першої дози і близько 10 секунд другої.

Ключові слова: флокуляція шламів, дрібнодисперсні шлами, шлами газоочищення, модуль очищення, виробничтва феросплавів.

\section{Introduction}

Metallurgical production is accompanied by the formation of a huge amount of industrial waste (IW), reaching $30 \%$ of the output of steel. About $80 \%$ of them are slag, about $20 \%$ of dust and slime of gas treatment [1].
Today Ukrainian enterprises discharge over 2 billion $\mathrm{m}^{3} /$ year of untreated and insufficiently treated sewage into water bodies, which leads to a deterioration of the ecological condition of water bodies and the surrounding natural environment as a whole. The most dangerous is the waste water of metallurgical enterprises containing 